\title{
URINE NEUTROPHIL GELATINASE-ASSOCIATED LIPOCALIN DETERMINATION AS A DONOR AUXILIARY EXAMINATION METHOD - FIRST RESULTS
}

\author{
Aleksandrs Mạ̣cevs*, **, Jānis Jušinskis*, **, Sergejs Truškovs**, Viktors Ševeḷevs**, \\ and Rafails Rozentāls*, ** \\ * Laboratory of Transplantology, Rīga Stradiṇš University, Dzirciema iela 16, Rīga, LATVIA \\ ** Pauls Stradinš University Hospital, Latvian Transplantation Centre, Pilsonu iela 13, Rīga, LV-1002, LATVIA; \\ Aleksandrs.Malcevs@rsu.Iv; Janis.Jusinskis@rsu.Iv; Jushinskis@transplantation.Iv; Rafails.Rozentals@rsu.Iv \\ Contributed by Rafails Rozentāls
}

\begin{abstract}
A growing lack of donor organs has caused extension of criteria for deceased donation. Therefore, elderly donors and donors with increased serum creatinine levels, as well as donors after cardiocirculatory death, have become used more frequently. The examination of such donors is strongly limited due to the lack of time, and the determination of the quality of donor organs is still based on clinical and laboratory screening data of donors. Implementation of new examination methods is required to determine the functional condition of donor organs more accurately, which would allow correct selection of donors. This retrospective study included all consecutive deceased donor (DD) kidney transplantations (KTx) performed in a single centre during the period from 1 January 2010 till 30 November 2011. The donor examination was supplemented by the urine neutrophil gelatinase-associated lipocalin (U-NGAL) test. Recipients were available for follow-up for at least 12 months (totally $97 \mathrm{KTX}$ from $63 \mathrm{DD}$ ). All cases were divided into four groups according to U-NGAL and serum creatinine (S-Crea) levels in donors: group I - normal U-NGAL and S-Crea $(n=70)$; group II - elevated U-NGAL and S-Crea $(n=10)$; group III - elevated U-NGAL and normal S-Crea ( $n=9)$; group IV - normal U-NGAL and elevated S-Crea $(n=8)$. Information about rates of delayed graft function (DGF) and immediate graft function (IGF), acute rejection (AR), recipient S-Crea levels during the first post-transplant year for functioning grafts, graft losses and recipient deaths were summarised. Donor urine NGAL level showed moderate correlation with donor S-creatinie level $(r=0.543, \mathrm{P}<0.001)$. DGF was observed in 20 recipients $(21 \%)$ and demonstrated association with increased donor S-creatinine $(0.135 \pm 0.061$ vs. 0.108 $\pm 0.04 \mathrm{mmol} / \mathrm{I}$ in IGF, $p<0.05$ ). Combination of increased donor S-Crea and U-NGAL (group II) was associated with worse graft function during the first year after transplantation. Recipients in group III had increased S-Crea at the time of discharge from hospital and at one year after transplantation. One-year death censored graft survival and recipient survival was similar in all groups $(\mathrm{P}=\mathrm{NS})$. Determination of U-NGAL can be used as a donor auxiliary examination method for determination of the kidney graft functional condition and for prediction of post-transplant results. The study needs to be continued with a higher number of observations and longer post-transplant follow-up.
\end{abstract}

Key words: kidney transplantation, deceased donors, urine NGAL.

\section{INTRODUCTION}

Kidney transplantation (KTx) is the most effective method of treatment of end stage chronic kidney disease (CKD). Growing donor organ shortage has caused a need to extend selection criteria for deceased donation. Therefore, elderly donors and donors with increased serum creatinine (S-Crea) level, as well as donors after cardiocirculatory death have become used more frequently (Rozental et al., 2012). The use of such donors may lead the retrieval of poor quality grafts and worse post-transplant results. Examination of deceased donors (DD) is strongly limited due to the lack of time, and presently determination of the quality of donor organs is based mainly on clinical and laboratory screening data. Histological examination of "donor 0 biopsy" is presently the "gold standard" for donor organ quality determination, but much time is requires for preparation and examination of histological samples, which significantly extends cold ischemia time (CIT), increasing risk of post-transplant complications (Van der Vliet et al., 2011).

The correct and careful selection procedure for deceased donation requires implementation of new examination methods for determining functional condition of donor or- 
gans. Introduction of new quick and more accurate tests may improve correct selection of donors, reducing the risk of transplantation of organs with critically poor quality. Also, precise determination of the quality of organs recovered from "doubtful" donors may even increase the number of renal transplants by recognition of discarded organs as suitable for transplantation.

Urine neutrophil gelatinase-associated lipocalin (U-NGAL) is a biomarker of acute kidney injury (Haase et al., 2009). NGAL is a $25-\mathrm{kDa}$ protein that is expressed in neutrophil leukocytes and human epithelium. NGAL is involved in iron transportation, regulates cell growth and differentiation, and is a congenital component of antibacterial immunity (Kjeldsen et al., 1993).

Two NGAL secretion localisations have been described systemic NGAL and renal NGAL. Systemic NGAL is released from liver, spleen and activated neutrophils. It is filtered through glomerular tufts and is reabsorbed into proximal convoluted canals (Kjeldsen et al., 1993). If there is no systemic inflammation, filtered NGAL does not promote urine NGAL secretion (Parikh et al., 2006). In case of acute renal injury, NGAL is rapidly produced in the loop of Henle and distal canals and is secreted into urine. In urine, NGAL is resistant to proteolytic cleavage and its level can be determined (Mishra et al., 2003).

The use of this biomarker as an auxiliary donor examination method may be useful for clarification of the functional condition of donor kidneys.

\section{MATERIALS AND METHODS}

This retrospective study included all consecutive DD KTx performed in a single centre during the period from 1 January 2010 till 30 November 2011. Donor examination was supplemented with the U-NGAL test. Recipients were available for follow-up for at least 12 months (total $97 \mathrm{KTx}$ from $63 \mathrm{DD}$, mean donor age $49.2 \pm 11.4$ years, mean recipient age $47.3 \pm 13.5$ years).

The main CKD diagnoses were chronic glomerulonephritis $(\mathrm{n}=63,65 \%)$, kidney polycystosis $(\mathrm{n}=12,12 \%)$ and diabetic nephropathy $(\mathrm{n}=10,10 \%)$.

Donor organs were recovered and transplanted according to current and accredited medical technology. Donor organ recovery utilised in situ preservation in Histidine-tryptophanketoglutarate (HTK) solution. The mean CIT was $17.35 \pm$ 2.39 hours; warm ischemia time did not exceed 20 minutes.

All cases were divided into four groups according to donor U-NGAL and S-Crea levels:

Group I: Recipients who received kidneys from DD with normal U-NGAL and normal S-Crea $(\mathrm{n}=70$, recipient mean age $47.2 \pm 13.2$ )

Group II: Recipients who received kidneys from donors with elevated U-NGAL and elevated S-Crea $(n=10$, recipient mean age $42.1 \pm 18.2$ )

Group III: Recipients who received kidneys from donors with elevated U-NGAL and normal S-Crea $(n=9$, recipient mean age $51.4 \pm 12.3$ )

Group IV: Recipients who received kidneys from donors with normal U-NGAL and elevated S-Crea $(n=8$, recipient mean age $48.8 \pm 12.9$ )

Demographical description of groups is showed in Table 1.

Chemiluminescent microparticle immunoassay was used to measure U-NGAL level (Abbott Architect ${ }^{\circledR}$ ).

Groups were compared for rates of delayed graft function (DGF) and immediate graft function (IGF), acute rejection reactions (AR), recipient S-Crea level during the first posttransplant year (for functioning grafts), kidney graft loss

DEMOGRAPHICAL AND CLINICAL FEATURES OF RECIPIENT GROUPS

\begin{tabular}{|c|c|c|c|c|}
\hline & Group I & Group II & Group III & Group IV \\
\hline Number of donors & 47 & 6 & 5 & 6 \\
\hline Number of haemodynamically unstable donors & $4(8.5 \%)$ & $6(100 \%)$ & $5(100 \%)$ & $1(16.7 \%)$ \\
\hline Donor age, years $($ mean $\pm \mathrm{SD})$ & $49.3 \pm 11.6$ & $50.3 \pm 6.7$ & $54.2 \pm 7.1$ & $42.8 \pm 15.3$ \\
\hline Donor weight, $\mathrm{kg}($ mean $\pm \mathrm{SD})$ & $80.4 \pm 16.8$ & $84.7 \pm 13.6$ & $82.0 \pm 13.8$ & $96.3 \pm 30.4$ \\
\hline Urine NGAL, ng/ml (mean \pm SD) & $25.9 \pm 20.4$ & $291.9 \pm 202.5$ & $339.9 \pm 310.8$ & $22.4 \pm 11.1$ \\
\hline Serum creatinine, mmol/l (mean $\pm \mathrm{SD})$ & $0.09 \pm 0.02$ & $0.21 \pm 0.04$ & $0.11 \pm 0.04$ & $0.17 \pm 0.04$ \\
\hline Number of recipients & 70 & 10 & 9 & 8 \\
\hline Recipient age, years (mean \pm SD) & $47.2 \pm 13.2$ & $42.1 \pm 18.2$ & $51.4 \pm 13.2$ & $48.8 \pm 12.9$ \\
\hline Recipientd gender (male vs. female) & $30 / 40$ & $5 / 5$ & $2 / 7$ & $6 / 2$ \\
\hline Cold ischemia time, hours (mean $\pm \mathrm{SD}$ ) & $17.3 \pm 4.6$ & $12.8 \pm 8.2$ & $18.2 \pm 4.4$ & $22.0 \pm 1.4$ \\
\hline Delayed graft function & $13(18.6 \%)$ & $5(50 \%)$ & $1(11.1 \%)$ & $1(12.5 \%)$ \\
\hline Death censored one year graft survival, \% & $91 \%$ & $80 \%$ & $89 \%$ & $75 \%$ \\
\hline Recipientd one year survival, $\%$ & $100 \%$ & $100 \%$ & $100 \%$ & $87 \%$ \\
\hline
\end{tabular}


and recipient death. DGF was defined as the need to perform at least one dialysis session during the first posttransplant week. AR episodes were diagnosed by graft biopsy (Banff 2007 classification) and treated by steroid pulse, or, in cases of steroid-resistant cases, by anti-thymocyte globulin.

According to the laboratory reference interval, the U-NGAL level was considered increased if $\geq 100 \mathrm{ng} / \mathrm{ml}$, and the S-Crea level was considered increased if $\geq 0.15 \mathrm{mmol} / \mathrm{l}$.

Donors were considered haemodynamically instable if there were episodes of asystole and/or drops of systolic blood pressure below $80 \mathrm{~mm} \mathrm{Hg}$ before organ explantation.

Immunosuppression consisted of induction by steroids and monoclonal or polyclonal antilymphocyte antibodies, and maintenance immunosuppression by oral steroid, antiproliferative agents and calcinerine inhibitors.

All data were entered and processed by Microsoft Office Excel 2007 and SPSS 13.0 (SPSS Inc.) software.

\section{RESULTS}

The mean donor U-NGAL level was $83.79 \pm 162.24 \mathrm{ng} / \mathrm{ml}$ and S-Crea level was $0.11 \pm 0.05 \mathrm{mmol} / \mathrm{l}$. Donor U-NGAL level showed moderate correlation with donor S-Crea level (r $=0.543, P<0.001)$.

Donor U-NGAL and S-Crea levels were not significantly correlated with other donor haematological and biochemical parameters (leukocyte and erythrocyte counts, haemoglobin level, serum alanine aminotransferase (ALT) and aspartate aminotransferase (AST) levels), and also with donor age, weight, body mass index (BMI), and duration of stay in intensive care unit and use of vasopressors.

Haemodynamic instability was observed in 16 donors $(25 \%)$. The U-NGAL level in donors with haemodynamic instability was statistically higher compared to donors with stabile haemodynamics $(243.41 \pm 257.86$ vs. $29.30 \pm 37.99$ ng/ml, $P<0.001)$. The S-Crea level in donors with haemodynamic instability was also statistically higher than in donors with stabile haemodynamic $(0.15 \pm 0.06$ vs. $0.10 \pm$ $0.03 \mathrm{mmol} / \mathrm{l}, P<0.001)$.

DGF was observed in 20 recipients $(21 \%)$ and demonstrated association with increased donor S-Crea level $(0.135 \pm 0.061$ $\mathrm{mmol} / \mathrm{l}$ vs. $0.108 \pm 0.04$ in IGF, $\mathrm{p}=0.03$ ). The duration of stay in the intensive care unit and CIT did not show association with DGF.

During the follow-up period AR episodes were observed in 38 recipients $(39 \%)$ and showed no association with donor U-NGAL and S-Crea levels ( $P=$ NS for both).

Analysis of the demographical and clinical features of donors and recipients (Table 1) revealed significantly higher prevalence of haemodynamically unstable donors in groups II and III (compared with other two groups) and higher donor mean weight in group IV compared with group I $(P<$ 0.05 for all).

Analysis of post-transplant results (Table 1) showed higher rate of DGF in group II compared with groups I, III and IV, and more frequent development of AR in group III compared with groups I and II $(P<0.05$ for all). There also were no significant differences in graft and recipient survival between groups ( $P=\mathrm{NS}$ in all cases).

Analysis of kidney graft function in groups also showed significant differences (Table 2). Group I had significantly lower S-Crea compared with group II at the time of discharge from hospital $(P=0.005)$, and at six, nine and twelve months post- transplant $(P<0.05, P=0.012$ and $P=$ 0.001 , respectively). Group I also had significantly lower S-Crea compared with group III at the time of discharge from hospital $(P<0.05)$ and twelve months after transplantation $(P=0.011)$ and with group IV at the time of discharge from hospital $(P<0.001)$. Comparison of groups II, III and IV did not show statistically significant differences between them $(P=\mathrm{NS}$ in all cases).

Cross-sectional analysis of combinations of both elevated donor U-NGAL and elevated S-Crea showed an increase in sensitivity predicting worse graft function during the first year after transplantation (Table 3 ).

\section{DISCUSSION}

Serum creatinine level and its clearance has remained the main marker for evaluation of the functional status of kidneys for many years, however, increase in its level appear too late, when kidney function is already seriously damaged (Star et al., 2002). Improvement in the quality of transplantation is closely associated with the quality of recovered donor organs, the precision of which can be achieved only by implementation of new diagnostic methods, including the

Table 2

RECIPIENT S-CREA LEVELS DURING THE FIRST YEAR AFTER TRANSPLANTATION

\begin{tabular}{|c|c|c|c|c|}
\hline Recipient S-Crea level & Group I & Group II & Group III & Group IV \\
\hline At discharge from hospital, mmol/l (mean \pm SD) & $0.13 \pm 0.04$ & $0.18 \pm 0.12$ & $0.17 \pm 0.08$ & $0.20 \pm 0.08$ \\
\hline 3 months after transplnatation, $\mathrm{mmol} / \mathrm{l}($ mean $\pm \mathrm{SD})$ & $0.14 \pm 0.07$ & $0.18 \pm 0.12$ & $0.16 \pm 0.05$ & $0.17 \pm 0.07$ \\
\hline 6 months after transplantation, $\mathrm{mmol} / \mathrm{l}($ mean $\pm \mathrm{SD})$ & $0.14 \pm 0.07$ & $0.20 \pm 0.11$ & $0.17 \pm 0.09$ & $0.17 \pm 0.05$ \\
\hline 9 months after transplantation, $\mathrm{mmol} / \mathrm{l}($ mean $\pm \mathrm{SD})$ & $0.14 \pm 0.06$ & $0.21 \pm 0.12$ & $0.19 \pm 0.15$ & $0.17 \pm 0.04$ \\
\hline 12 months after transplantation, $\mathrm{mmol} / \mathrm{l}($ mean $\pm \mathrm{SD})$ & $0.14 \pm 0.06$ & $0.27 \pm 0.19$ & $0.23 \pm 0.21$ & $0.17 \pm 0.05$ \\
\hline
\end{tabular}


SENSITIVITY AND SPECIFICITY OF DONOR U-NGAL AND S-CREA FOR PREDICTION OF RENAL GRAFT FUNCTION DURING THE FIRST POST-TRANSPLANT YEAR

\begin{tabular}{|c|c|c|c|c|c|c|}
\hline \multirow[t]{2}{*}{ Donor factor } & \multirow{2}{*}{$\begin{array}{c}\text { Sensitivity and } \\
\text { specificity }\end{array}$} & \multicolumn{5}{|c|}{ Increased S-Crea in post-transplant period: } \\
\hline & & at discharge & 3 months & 6 months & 9 months & 12 months \\
\hline \multirow[t]{2}{*}{ Elevated donor U- NGAL } & Sensitivity & $35 \%$ & $30 \%$ & $30 \%$ & $25 \%$ & $31 \%$ \\
\hline & Specificity & $86 \%$ & $89 \%$ & $90 \%$ & $87 \%$ & $89 \%$ \\
\hline \multirow[t]{2}{*}{ Elevated donor S-Crea } & Sensitivity & $32 \%$ & $18 \%$ & $25 \%$ & $21 \%$ & $24 \%$ \\
\hline & Specificity & $93 \%$ & $91 \%$ & $94 \%$ & $92 \%$ & $94 \%$ \\
\hline \multirow[t]{2}{*}{ Elevated donor U-NGAL S-Crea } & Sensitivity & $48 \%$ & $36 \%$ & $38 \%$ & $32 \%$ & $38 \%$ \\
\hline & Specificity & $85 \%$ & $86 \%$ & $86 \%$ & $83 \%$ & $86 \%$ \\
\hline
\end{tabular}

use of biomarkers. Graft function depends on several, both donor- and recipient-related, factors (Jushinskis et al., 2009). However, the functional condition of the donor organ before explantation is one of the most significant factors. U-NGAL here appears to be a promising marker of early kidney damage, as it increases in level much earlier than S-Crea (Mishra et al., 2005; Hirsch et al., 2007). However, there are only few scattered studies on testing of the use of this marker for evaluation of donor kidneys.

In our study donor U-NGAL level showed correlation with donor S-Crea level, indicating the relation of this biomarker to kidney injury. However, U-NGAL level failed to show association with DGF, while increased donor S-Crea level was associated with the development of DGF. This may be explained by the fact that increase in the level of U-NGAL may reflect only early stage of kidney damage, which does not always lead to functional insufficiency. The donor SCrea level in this respect was more predictive, as increase of its level indicates a more serious pathology in donor kidney.

The development of acute rejection was not associated elevation of both markers, showing that the initial functional condition of a donor kidneys does not have much effect on the immunological component.

The most promising means of evaluation was to use the combination of both markers, as the increase of one or both markers was related to development of DGF (higher in cases of elevated donor U-NGAL and S-Crea) and AR (higher in cases of elevated donor U-NGAL and normal S-Crea). Differences were also seen in kidney graft function in the post-transplant period, with the best results observed in recipients who received their kidneys from donors with normal U-NGAL and S-Crea. However, increase in the level of donor U-NGAL with or without elevation of S-Crea showed poorer kidney graft function up to 1 year after transplantation, probably associated with ischemic kidney damage in the pre-explantation period and more frequent AR.

Unfortunately, this study had a limited number of cases with different combinations of increased donor U-NGAL and S-Crea. Further study in this field requires higher number of observations and longer follow-up period to obtain more precise results.
In conclusion, determination of U-NGAL can be used as a donor auxiliary examination method for determination of kidney graft functional condition and for prediction of post-transplant results. The study must be continued with a higher number of observations and longer post-transplant follow-up.

\section{REFERENCES}

Haase, M., Bellomo, R., Devarajan, P., Schlattmann, P., Haase-Fielitz, A. (2009). Accuracy of neutrophil-gelatinase associated lipocalin (NGAL) in diagnosis and prognosis in acute kidney injury. A systematic review and meta-analysis. Amer. J. Kidney Dis. 54, 1012.

Hirsch, R., Dent, C., Pfriem, H., Allen, J., Beekman III, R. H., Ma, Q., Dastrala, S., Bennett, M., Mitsnefes, M., Devarajan, P. (2007). NGAL is an early predictive biomarker of contrast-induced nephropathy in children. Pediatr. Nephrol., 22 (12), 2089-2095.

Jushinskis, J., Trushkov, S., Bicans, J., Suhorukov, V., Shevelev, V., Ziedina, I., Rozental, R. (2009). Risk factors for the development of delayed graft function in deceased donor renal transplants. Transplant. Proc.. 41 (2), 746-748.

Kjeldsen, L., Johnesen, A. H., Sengelov, H., Borregaard, N. (1993). Isolation and primary structure of NGAL, a novel protein associated with human neutrophil gelatinase. J. Biol. Chem., 268, 10425

Mishra, J., Ma, Q., Prada, A., Mitsnefes, M., Zahedi, K., Yang, J., Barasch, J., Devarajan, P. (2003). Identification of neutrophil gelatinase-associated lipocalin as a novel early urinary biomarker for ischemic renal injury. $J$. Amer. Soc. Nephrol., 14 (10), 2534-2543.

Mishra, J., Dent, C., Tarabishi, R., Mitsnefes, M. M., Ma, Q., Kelly, C., Ruff, S. M., Zahedi, K., Shao, M., Bean, J., Mori, K., Barasch, J., Devarajan, P. (2005). Neutrophil gelatinase-associated lipocalin (NGAL) as a biomarker for acute renal injury after cardiac surgery. The Lancet, 365 (9466), 1231-1238.

Parikh, C. R., Jani, A., Mishra, J., Ma, Q., Kelly, C., Barasch, J., Edelstein, C. L., Devarajan, P. (2006). Urine NGAL and IL-18 are predictive biomarkers for delayed graft function following kidney transplantation. Amer. J. Transplant. 6, 1639.

Star, R., Hostetter, T., Hortin, G. L. (2002). New markers for kidney disease. Clin. Chem., 48 (9), 1375-1376.

Van der Vliet, J. A., Warlé, M. C., Cheung, C. L. S., Teerenstra, S., Hoitsma, A. J. (2011). Influence of prolonged cold ischemia in renal transplantation. Clin. Transplant., 25 (6), 612-616.

Розенталь Р. Л., Юшинскис Я. Л., Трушков С. В., Бицанс Я. Б., Шевелев В. Н., Мальцев А. В. (2012). Трансплантация почек, полученных у доноров после остановки сердца [Kidney transplantation from donors after cardiac death]. Вестник трансплан. искусств. орг., 24 (1), 15-18. 

METODE - PIRMIE REZULTĀTI

Pieaugošs donororgānu trūkums ir iemesls mirušo donoru atlases kritēriju paplašināšanai, līdz ar ko arvien biežāk tiek izmantoti vecāka gadagājuma donori, donori ar paaugstināto seruma kreatinīna līmeni, ka arī donori pēc sirdsdarbības apstāšanās. Šādu donoru izmeklēšana ir stipri ierobežota laika trūkuma dēḷ un donororgāna kvalitātes noteikšana joprojām balstās uz klīniski laboratoriskiem donora skrīninga datiem. Ir nepieciešams ieviest jaunas izmeklēšanas metodes donororgānu funkcionāla stāvokḷa precizēšanai, kas ḷautu veikt korektu donoru atlasi. Šajā retrospektīvajā pētījumā tika iekḷautas visas secīgas transplantācijas $(\mathrm{n}=97)$, kas tika veiktas no mirušiem donoriem $(\mathrm{n}=63)$ laika periodā no 2010. gada 1. janvāra līdz 2011. gada 30. novembrim, kur tika noteikts donora urīna neitrofilu asociētā želatināzes lipokalīna (NGAL) līmenis un recipienti bija izsekojami vismaz vienu gadu pēc transplantācijas. Tika apkopota informācija par donoru urīna NGAL līmeni, atlikto transplantāta funkciju biežumu, akūtām atgrūšanas reakcijām, kreatinīna līmeni pirmajā pēctransplantācijas gadā funkcionējošiem transplantātiem, donororgānu zaudējumiem un recipientu nāvēm gada laikā. Tika novērota vidēji stingra donora urīna NGAL un seruma kreatinīna korelācija $(\mathrm{r}=0,543, P<0,001)$. Atlikta transplantāta funkcija novērota 20 recipientiem un uzrādīja statistiski ticamu saistību ar paaugstināto donora kreatinīna līmeni $(0,135 \pm 0,061 \mathrm{vs} .0,108 \pm 0,04 \mathrm{mmol} / \mathrm{l}$ tūlītējas funkcijas gadījumā, $P<0,05)$. Gadījumos, kad tika konstatēts paaugstināts donora seruma kreatinīna līmenis un paaugstināts urīna NGAL līmenis, tika novērota sliktāka transplantāta funkcija pirmajā gadā pēc transplantācijas. Transplantācijas gadījumos no donoriem ar paaugstinātu urīna NGAL līmeni, bet normālu seruma kreatinīna līmeni, tika novērota sliktāka transplantāta funkcija, recipientam izrakstoties no stacionāra un vienu gadu pēc transplantācijas. Viena gada transplantāta dzīvildze un recipientu dzīvildze starp grupām neatšķ̄īās. Jāsecina, ka donora urīna NGAL līmeņa noteikšanu var izmantot kā donora papildizmeklēšanas metodi transplantāta funkcionāla stāvokḷa noteikšanai un pēctransplantācijas rezultātu prognozē̌sanai. Pētījums ir jāturpina ar lielāku respondentu skaitu un ilgāku recipientu novērošanas periodu. 